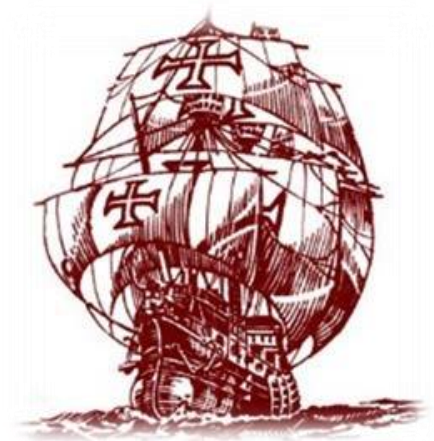

\author{
Nau Literária: crítica e teoria de literaturas \\ www.seer.ufrgs.br/nauliteraria \\ ISSN 1981-4526 - PPG-LET-UFRGS - Porto Alegre \\ Vol. 11 N. 02 \\ Literatura e Guerra
}

\title{
NADA DE NOVO TANTO NO FRONT QUANTO NO MUNDO
}

\author{
MÁrcia Rodrigues GONÇALVES ${ }^{\mathrm{i}}$
}

Resumo: Nada de novo no front, de Erich Maria Remarque, é o relato de um soldado raso alemão, Paul Bäumer, que vivenciou o cotidiano da I Guerra Mundial. Quando foi publicado, em 1929, esse livro questionou até que ponto a pátria poderia dispor de seus cidadãos a fim de colocar em prática decisões elaboradas por lideranças políticas no conforto de seus gabinetes. Por mais que o romance seja uma realidade paralela criada por um escritor, a trama baseia-se em fatos reais, refletindo acontecimentos históricos e trazendo memórias que os livros didáticos não conseguem alcançar. As descrições dos mais intensos sofrimentos, como a fome, o frio, o medo e a morte, formam um panorama do que realmente foi o primeiro maior conflito do século XX, diferentemente da visão dada pelos articuladores desse embate. $\mathrm{O}$ embrutecimento do ser, a impossibilidade de perspectiva quanto ao futuro e a noção da falta de sentido dos conflitos são o mote desse romance, que capitaneou a lista das literaturas distópicas, advindas do desencanto em relação ao mundo, ao progresso científico e ao ser humano.

Palavras-chave: Nada de novo no front. Literatura. Distopia. I Guerra Mundial.

Abstract: All Quiet on the Western Front, by Erich Maria Remarque, is the story of a German Private, Paul Bäumer, who experienced the daily living of the $1^{\text {st }}$ World War. When it was published, this book questioned to what extent a country could use their citizens in order to put into practice the decisions taken by political leaders in the comfort of their offices. Although the novel depicts a parallel reality created by a writer, the plot is based on true facts, reflecting historic happenings and bringing memories which the textbooks are not able to reach. The descriptions of the most intense sufferings, such as hunger, coldness, fear and death, create a picture of what was the first real major conflict of the XX century, a vision totally different from the one held by the articulators of this war. The brutalization of the human being, the impossibility of finding a perspective for the future and the notion of lack of sense of these conflicts are the motto of this novel, a work which leaded the list of dystopian books resulting from the disillusion with the world, the scientific progress and the human being.

Keywords: All Quiet on the Western Front. Literature. Dystopia. ${ }^{\text {st }}$ World War

Milhões de homens, repudiando todo o sentimento humano e toda a espécie de razões, tinham de marchar do Ocidente para o Oriente dispostos a matar os seus semelhantes, tal qual, séculos antes, massas de homens tinham marchado do Oriente para o Ocidente matando igualmente o seu semelhante.

Guerra e Paz, Leon Tolstói, 1869. 
Dentre as várias obras que se ocuparam da guerra, pode-se eleger A Ilíada, de Homero, como cânone desse formato. Misturando mitologia e heróis, cujos feitos gloriosos foram eternizados, pode ser considerado o primeiro grande texto que versa sobre combates, envolvendo muitas pessoas e dois povos. A Guerra de Troia ocorreu supostamente na cidade de Ilion, pois, pela falta de suficientes evidências, não há comprovação de que tenha acontecido. Nessa epopeia, justificando o gênero, as atrocidades abundam e não são questionadas.

Nas guerras, no entanto, não existem heróis ou façanhas sobrenaturais; há pessoas normais, cheias de contradições, de medos, muitas vezes avessas ao ideal por qual lutam. Nada de novo no front, de Erich Maria Remarque, tornou-se um libelo das atrocidades vivenciadas por um soldado raso, Paul Bäumer. Diferentemente do amparo e da proteção dos deuses que povoaram a epopeia de Homero, essa personagem contava apenas com a própria sorte. Quando de sua publicação, em 1929, o livro contribuiu para alterar o pensamento que se formara em torno da I Guerra e dos soldados que dela participaram. Provocou reações antipatrióticas, questionando até que ponto a pátria poderia dominar o indivíduo. Várias vozes alemãs, muitas caladas à força, das mais diferentes ciências, altercaram acerca do uso da tecnologia que destruía populações em vez de beneficiá-las.

A sociedade civil europeia do início do século XX estava em suas casas, sofrendo com a falta de víveres e com as perdas de seus afetos, mas não conseguia dimensionar o que se passava no front; os que para lá se dirigiam eram aclamados heróis. O mérito de Nada de novo no front foi o de desmistificar o dia a dia de um grupo de soldados microcosmo do conflito inteiro - que teve sua juventude roubada pela esperança de defender seu país de inimigos estrangeiros: "As pessoas não tinham ideia do que estava por vir. Os mais sensatos eram realmente os pobres, os simples: viram logo que a guerra era uma desgraça, enquanto as classes mais altas não se continham de alegria [...]" (REMARQUE, 1981, p. 15).

\section{Guerra Mundial - um pequeno retrospecto}

Em consequência dessa mútua hostilidade primária dos seres humanos, a sociedade civilizada se vê permanentemente ameaçada de desintegração.

Sigmund Freud, O mal-estar da civilização, 1929.

Dentre os vários fatos que deflagraram o primeiro grande conflito do século $\mathrm{XX}$, pode-se elencar a insatisfação que grassava na Itália e na Alemanha em relação à Inglaterra e à França, pois o leão e a lis ${ }^{1}$ repartiram a seu bel prazer as colônias africanas e asiáticas, delas retirando rica matéria-prima, anulando as pretensões colonialistas dos italianos e dos alemães.

Ao mesmo tempo, a França não digerira a perda do território da Alsácia-Lorena, no final do século XIX, para a Alemanha, durante a guerra franco-prussiana. Os alemães,

\footnotetext{
${ }^{1}$ Desde a Idade Média, a Inglaterra tem como símbolo um leão, metáfora de sua força. Lis é uma redução de "flor-de-lis", símbolo da França, expressão cunhada, igualmente, no mesmo período histórico. Um dos romances, que faz parte da obra Os reis malditos, cujo autor é Maurice Druon, é denominado de $O$ lis $e$ o leão, que trata dos prenúncios da Guerra dos Cem Anos, conflito entre essas duas nações, que durou quase um século. As expressões “o leão e a lis” são, portanto, antonomásias desses países.
} 
ainda, tinham a pretensão de anexar todos os países de origem germânica, sentimento que foi denominado de pangermanismo. Os países se armavam, havia um clima de revanche no ar, embora em tempos de paz.

A crise balcânica - conflitos entre Áustria e Sérvia na península balcânica acirrou as diferenças nacionalistas entre os países europeus. Com o apoio da Rússia, os sérvios tentaram conter o expansionismo austríaco. Alemanha e Rússia igualmente se digladiavam porque a rota Constantinopla-Mediterrâneo do imperialismo russo cruzava com a rota Berlim-Constantinopla-Bagdá, do imperialismo alemão. O imperialismo gerava atritos nas colônias; o nacionalismo, atritos na Europa.

Esses elementos fermentaram de tal forma, que se iniciou a guerra entre a Tríplice Entente (França, Inglaterra e Rússia) e a Tríplice Aliança (Alemanha, Áustria e Itália), um combate que se imaginava rápido, mas que se alongou para uma guerra de trincheiras (ARRUDA; PILETTI, 1996, p. 265). Essa rede imbricada de valores e de interesses, alguns comuns entre si, foi o elemento que deflagrou o primeiro conflito de proporções mundiais (de 1914 a 1918), nação contra nação, nunca visto anteriormente, a I Guerra Mundial.

No começo, havia equilíbrio em número de habitantes e de soldados; diferentes eram os equipamentos e os recursos: a Entente não tinha canhões de longo alcance, mas dominava os mares graças ao poderio naval inglês (ARRUDA; PILETTI, 1996, p. 266). As perdas, no entanto, foram desastrosas para ambos os lados, totalizando oito milhões de mortos, sendo que somente a Alemanha perdeu em torno de 1.800 .000 soldados (três para cada cem habitantes). Além das mortes, houve um saldo de vinte milhões de inválidos, o que significou para a Europa um para cada dez trabalhadores (ARRUDA; PILETTI, 1996, p. 268).

\section{Um romance pacifista: Nada de novo no front}

Espera-se impedir os excessos mais grosseiros da violência brutal por si mesma, supondo-se o direito de usar a violência contra os criminosos; no entanto, a lei não é capaz de deitar a mão sobre as manifestações mais cautelosas e refinadas da agressividade humana.

Sigmund Freud, O mal-estar da civilização, 1929.

Erich Maria Remarque participou como soldado do front, na I Guerra Mundial, quando foi ferido várias vezes e, por isso, afastado do combate. Muito de sua experiência dolorosa foi retratada por intermédio do personagem Paul Bäumer - um adolescente recém-saído da escola para defender sua pátria. Em uma narrativa linear, o autor utiliza as primeiras pessoas do singular e do plural (nós, o grupo), construindo um relato introspectivo, com intuito confessional. Paul não problematiza, é uma personagem ingênua; o horror lhe parece natural, uma banalização. Os militares de alta patente não aparecem, porque não vão à parte intestina da guerra, mas um cabo é ridicularizado pela maneira patética como se comporta. Com um foco antimilitarista, o autor denuncia também os excessos cometidos quando dos treinamentos dos recrutas alemães.

Do mesmo conflito participou Ernest Hemingway, mas em situação bem mais confortável, pois não esteve tão próximo da batalha como Remarque. Adeus às armas, de Hemingway, foi publicado no mesmo ano em que Nada de novo no front, em 1929. A história igualmente tem um tom confessional, retrata um combatente norte-americano, 


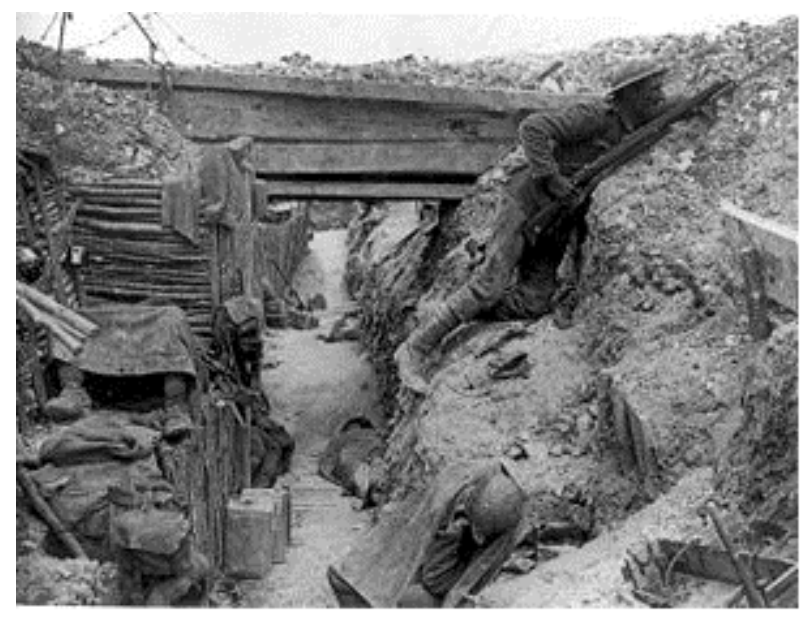

Henry $^{2}$, que se aliou espontaneamente às forças italianas, mas viveu o confronto mais distanciado dos horrores das trincheiras, visto que se tratava de um motorista de ambulância, que somente socorria aqueles que estavam feridos. Paul Bäumer, pelo contrário, relata com abundância de detalhes o sofrimento de passar horas inteiras acuado pelo frio, pelo medo, pela fome, sempre na iminência de que alguma granada pudesse atingi-lo ou de que uma bomba de gás pudesse alcançá-lo. "A frente é uma jaula, dentro da qual a gente tem de esperar nervosamente os acontecimentos" (REMARQUE, 1981, p. $86) .^{3}$

Havia momentos em que o pouco alimento, para vários dias, disponibilizado aos soldados, tinha de ser repartido com as ratazanas dentro das trincheiras para que elas não os mordessem; em outras ocasiões, havia bastante comida, porque as baixas do batalhão eram tamanhas, que sobrava muito para os que sobreviviam.

Junto com o medo constante de morrer, havia as perdas dos amigos - colegas de escola - e a consequente brutalização humana: "Perdemos toda a noção de solidariedade; quase não nos reconhecemos [...]" (REMARQUE, 1981, p. 98). Predomina no romance, portanto, ao contrário das epopeias, a visão dos perdedores - heróis não pelo sucesso, mas pela perda; não havia saída, não havia volta, seria inverossímil ganhar. O romance de Remarque remodela a representação do tema da guerra até então, pois a narrativa em primeira pessoa não se coaduna com o relato épico - cânone desse formato.

Mesmo diante de tanto sofrimento, há momentos de compaixão como, por exemplo, quando o protagonista reparte com os prisioneiros russos um pouco de comida: "À noite, passo a geleia nos bolinhos, e como alguns [...] e então saio para dá-los aos russos [...] foi minha própria mãe quem os fritou [...]" (REMARQUE, 1981, p. 160). Paul Bäumer dá-se conta de que os inimigos são pessoas comuns, recrutadas pelo mesmo motivo que ele o fora - a ilusão de defender a pátria e de voltar para seus lares. Remarque desconstrói o conceito de nacionalidade, porque a guerra desperta sentimentos contraditórios (de pertencimento e

\footnotetext{
2 Alguns críticos salientam a semelhança do nome da personagem com o nome do autor - Henry e Hemingway, tratando-se, possivelmente, de uma corruptela do sobrenome de Ernest. Classifica-se Adeus às armas como um romance autobiográfico por tantas semelhanças que contém acerca da estada do autor na Europa, da forma e do motivo pelo qual ambos (autor e personagem) alistaram-se e, igualmente, como sobreviveram nos tempos de escassez europeia - tanto o personagem como o autor recebiam contribuições pecuniárias de seus parentes norte-americanos. Cabe lembra que Hemingway, tal qual Henry, alistou-se como motorista de ambulância (a miopia de Hemingway não o permitira ir ao front) e também teve um relacionamento amoroso com uma enfermeira - tal qual o protagonista.

${ }^{3}$ Durante a maior parte da Primeira Guerra Mundial, Forças Aliadas e Alemãs ficaram estacionadas em uma guerra de trincheira ao longo da Frente Ocidental. Nessa imagem, há vários cadáveres junto com o soldado que, supostamente, tenta atacar para defender-se; cena que ilustra a narrativa de Paul. Fonte: <http://pt.wikipedia.org/wiki/Frente_Ocidental_(Primeira_Guerra_Mundial)>. Acesso em: 25 jan. 2012.
} 
de repulsa à pátria), ainda mais porque o popular é sempre a grande vítima. "Nada sei sobre eles, só que são prisioneiros [...] vejo por trás deles apenas a dor anônima da criatura humana, a terrível melancolia da vida, a falta de piedade dos homens [...]" (REMARQUE, 1981, p. 156).

O narrador relata a falta de tempo para treinar os novos recrutas, visto que o andamento da guerra não estava favorável à Alemanha: havia muitas baixas e a necessidade de reposição de artilheiros era iminente. Homens de todas as idades foram chamados pela urgência de manterem-se soldados ativos nas trincheiras, ou seja, todos eram convocados, tanto os mais maduros quanto os adolescentes. A inexperiência dos novos alistados comprometia, mais ainda, o andamento do conflito, pois muitos eram mortos pela incipiência e por atitudes precipitadas, geradas pelo medo: um ciclo mórbido crescente de mortes e de ferimentos graves: "Para cada veterano, morrem de cinco a dez recrutas" (REMARQUE, 1981, p. 110). Muitas atitudes dos mais jovens, cujo desespero e despreparo para lidar com armas tão destruidoras acelerava suas mortes, revelam o cotidiano do front, não divulgado à sociedade: "[...] esses pobres diabos corajosos [...] com o peito, o ventre, os braços e as pernas dilacerados, soluçam baixinho pelas suas mães, e calam-se assim que se olha para eles!" (REMARQUE, 1981, p. 109).

O conflito cada vez mais desfavorecia os alemães pela escassez de recursos humanos, pela falta de leitos aos feridos, pela pouca comida e pela quantidade expressiva de mortes que se sucediam. Os piolhos, a gripe, o tifo, a fome, a disenteria, a neve e a falta de assistência adequada aos doentes contribuíam igualmente para o cenário desolador. Remarque destruiu o discurso ideológico da guerra por não acreditar que esse fosse o caminho mais adequado à resolução de conflitos e quando percebeu que toda uma geração foi perdida. $\mathrm{O}$ aprendizado individual não permaneceria, porque os jovens morreram antes de voltar e os que regressaram sofreram traumas que os deixaram inválidos física ou emocionalmente. "Não somos mais a juventude. Não queremos mais conquistar o mundo. [...] Estamos isolados dos que trabalham, da atividade, da ambição, do progresso. Não acreditamos mais nessas coisas; só acreditamos na guerra” (REMARQUE, 1981, p. 76).

Merece destaque a grande tecnologia presente, visível, complexa, que alcançava um poder de destruição nunca dantes visto: "Bombardeio, fogo cerrado, fogo de barragem, gás ${ }^{4}$, minas, tanques, metralhadoras, granadas de mão... são apenas palavras, mas encerram todo o horror do mundo" (REMARQUE, 1981, p. 111). Os ataques de gás, que matavam muitos em pouco tempo, aliados ao mau uso do equipamento de proteção (máscaras), renderam cenas chocantes, pois, conforme relata Paul Bäumer, os pulmões daqueles atingidos pelo gás se desmanchavam: "Achamos um abrigo cheio de homens com os rostos azulados e com os lábios negros [...] tiraram cedo demais as máscaras [...] engasgam com hemorragias e têm crises de asfixia, até morrer" (REMARQUE, 1981, p. 110).

\section{Contexto intelectual do período: autoexílio de grandes vultos}

\footnotetext{
${ }^{4}$ Ainda na Primeira Guerra Mundial, o gás mostarda foi usado pelos alemães contra os inimigos; os ingleses e os franceses utilizaram gases do sangue. Estima-se que nessa guerra houve mais de 100 mil mortos vítimas de armas químicas (MONTOYA).
} 
A inclinação para a agressão constitui, no homem, uma disposição instintiva original e autossubsistente, e retorno à minha opinião, de que ela é o maior impedimento à civilização.

Sigmund Freud, O mal-estar da civilização, 1929.

Apesar de a sociedade não conseguir mensurar adequadamente as consequências que a I Guerra trazia à Europa, em especial à Alemanha, grandes nomes levantaram-se contra o sacrifício de tantas vidas e contra a involução que se instaurou no cotidiano europeu. Intelectuais de prestígio, como Albert Einstein, Bertolt Brecht, Sigmund Freud, Walter Benjamin e Theodor W. Adorno, por meio de textos e de palestras, posicionaram-se contra o que acontecia e, consequentemente, foram vítimas, direta ou indiretamente, das sequelas da derrota da Alemanha e da ascensão de Adolf Hitler. Procuraram refúgio em outros países que os acolheram e, por conseguinte, tornaram-se personae non gratae à pátria em que nasceram.

Segundo Santos (2000), “[...] por causa da sua posição pacifista, logo no início da Primeira Guerra Mundial, Albert Einstein passou a enfrentar represálias políticas, inicialmente verbais e posteriormente através de atos de vandalismo." Em suas aulas, na Universidade de Berlim, começaram a acontecer distúrbios e, com a eleição de Hitler para o cargo de chanceler (1933), acirraram-se as contendas em relação a suas ideias (SANTOS, 2000). Por ser judeu, Einstein fugiu da Alemanha após o regime de Adolf Hitler ter iniciado a perseguição antissemita e xenófoba. Crawford relata que Einstein tinha um comportamento discreto, mas, quando se tornou famoso por suas teorias, passou a usar sua celebridade para a defesa de várias causas como o pacifismo, o sionismo e o desarmamento.

Kaufmann diz que "Brecht foi um dos primeiros a deixar o país, por saber o que o aguardava quando o partido de Hitler começasse a colocar em prática suas ameaças." Bertold Brecht foi um destacado dramaturgo, poeta e encenador alemão do século XX. Seus trabalhos artísticos e teóricos influenciaram profundamente o teatro contemporâneo. Publicou Legende vom toten Soldaten (Lenda do soldado morto), poema pacifista que se refere à Primeira Guerra Mundial e que teria insuflado o ódio dos nazistas ${ }^{5}$. Kauffmann acrescenta que não demoraria muito para que se iniciasse a fuga de outros intelectuais alemães, mas alguns, como "Carl Von Ossietzky, o detentor do Prêmio Nobel da Paz, em 1935, foi levado a um campo de concentração e morreu em consequência das torturas". Por questão de sobrevivência, alguns, como o escritor Erich Kästner, retiraram-se da vida pública, calando-se, e assim obtiveram sobrevida "ao 'reino de mil anos' que Hitler pretendia instituir." Kaufmann lembra mais alguns que conseguiram escapar, como os escritores Lion Feuchtwanger, Thomas Mann, Erich Maria Remarque, os músicos Kleiber, Busch, Klemperer e muitos outros.

Barifouse (2009) relata que "até 1932, a Alemanha havia ganhado 33 dos 100 prêmios Nobel de Ciência; nos 27 anos seguintes, esse número se reduziria a oito." Acrescenta ainda que "a supremacia germânica era indiscutível: conjugava força militar e

\footnotetext{
${ }^{5}$ Esse poema zomba do modo como os alemães faziam a reposição dos combatentes mortos: como faltassem soldados ao exército do Império Alemão, decidiu-se desenterrar um soldado que morrera, vesti-lo com um novo uniforme e arranjá-lo para que passasse pelo exame médico e fosse mandado de volta ao front. Sob os aplausos do clero e dos representantes do grande capital, o defunto foi enviado ao campo de batalha para morrer como herói (KAUFMANN).
} 
eficiência econômica, tendo a pesquisa científica como base para a indústria”. A fuga daqueles que não concordavam com a ideologia que se formava provocou grande perda intelectual em virtude das ideias nazistas. "Seu anti-intelectualismo ditava que a universidade devia priorizar a ciência militar, além de formar a vontade e o caráter dos estudantes. [...] Apenas no primeiro ano de governo, cerca de 2.600 acadêmicos saíram do país"' (BARIFOUSE, 2009).

Nem mesmo a alcunha de Pai da Psicanálise por seus estudos acerca da psique humana livrou Sigmund Freud da fúria ariana. Igualmente judeu, foi mais um dos que necessitaram escapar de seu país. Morou em Viena até 1938, mas com a ascensão do nazismo refugiou-se na Inglaterra. Seus escritos acerca da psicanálise, suas ideias sobre id, ego e superego levantaram inquietações, pois muitos de seus artigos misturam descobertas científicas mescladas ao contexto sócio-econômico-cultural em que parte da Europa, em especial a Alemanha, estava inserida.

Em 1933, os nazistas baniram e queimaram os livros de Remarque, alegando ser ele descendente de judeus franceses (Kramer, no original, Remark lido de trás para frente). Os horrores relatados por Remarque, entretanto, não passaram ao largo dos filósofos alemães que se uniram em torno da Escola de Frankfurt. Esses pensadores, cuja origem em sua maioria era judaica, dentre eles, Walter Benjamin, Theodor Adorno e Max Horkheimer, sofreram em suas vidas pessoais os efeitos do novo modelo de regime que começava a se formar.

Walter Benjamin foi um filósofo judeu, interessado pelo marxismo, juntamente com Theodor Adorno. Fez parte da Escola de Frankfurt da qual foi mais um inspirador do que um membro. Refugiou-se na Itália, de 1934 a 1935, igualmente fugindo da perseguição hitleriana. Em 1940, na fronteira com os Pirineus, suicidou-se, quando percebera que seria capturado pelos membros da Gestapo.

Theodor Adorno, também integrante da Escola de Frankfurt, foi um dos idealizadores da Teoria Crítica da Sociedade. Foi mais um daqueles tantos que, na década de 1930, "por serem de descendência judaica ou por inclinarem-se pelo socialismo, ou ambas as coisas, foram obrigados a emigrar para os Estados Unidos, naquilo que foi, talvez, a maior evasão de cérebros registrada na história contemporânea" (SCHILLING, 2003).

Max Horkheimer participou da I Guerra Mundial. Em seus estudos posteriores, conheceu Theodor Adorno, com o qual ajudou a fundar a Escola de Frankfurt. Em 1933, com o fechamento, pelos nazistas, do Instituto de Pesquisas Sociais, Horkheimer foi obrigado a abandonar a Alemanha, passando pela Suíça e chegando à Universidade de Columbia, em Nova York, nos EUA, onde instalou o Instituto.

\section{É possível somente progresso intelectual e científico?}

A primeira exigência da civilização, portanto, é a da justiça, ou seja, a garantia de que uma lei, uma vez criada, não será violada em favor de um indivíduo.

\footnotetext{
${ }^{6}$ Maiores detalhes acerca do assunto podem ser obtidos em $O$ segredo de Hitler: cientistas que escaparam da Alemanha nazista, de Jean Medawar e David Pyke. Trad. Antônio Nogueira Machado. Rio de Janeiro: Record, 2003, 308 páginas; livro que reconstitui a história da diáspora de cientistas judeus refugiados em outros países.
} 
Em Além do princípio do prazer (1920), Freud traz à luz o conceito de "neurose traumática". Relata que, ao término da guerra, "[...] surgiram numerosos casos dessa espécie" (2006, p. 139). O neurologista austríaco chegou a essa conclusão por observações feitas de casos que atendeu em seu consultório. Os sobreviventes da guerra sofreram baques emocionais tão violentos que os apagaram de suas memórias; fisicamente não sentiam dor, pânico ou medo, mas caracterizavam-se por um silêncio perturbador. Cada vez que a lembrança fosse verbalizada, a emoção seria revivida, por isso a opção renitente de não quererem contar detalhes, negando-se a falar sobre o assunto.

Em Nada de novo no front, a atitude de Paul Bäumer, quando visita seus pais, ilustra o conceito freudiano. O soldado sentiu-se desconcertado com as perguntas que lhe faziam, com a exposição a seu respeito que seu pai tentava fazer, da ilusão das pessoas em relação aos soldados; Bäumer não contou os problemas que vivenciava e não sentia vontade de conversar: "Compreendo que não saiba que estas coisas não podem ser contadas [...] mas é muito perigoso para mim transformar os acontecimentos em palavras" (REMARQUE, 1981, p. 136). Pensava constantemente nos colegas e nos amigos que deixara no front. Queria ficar recluso em seu quarto, em silêncio, em meio aos livros de que outrora tanto gostava. Sua postura, portanto, configura o trauma narrativo daqueles que voltaram da guerra. Em $O$ mal-estar da civilização, Freud retoma sua tese de silenciamento e acrescenta que:

Desde que superamos o erro de supor que o esquecimento com que nos achamos familiarizados significava a destruição do resíduo mnêmico — isto é, a sua aniquilação - ficamos inclinados a assumir o ponto de vista oposto, ou seja, o de que, na vida mental, nada do que uma vez se formou pode perecer - de que tudo é, de alguma maneira, preservado e que, em circunstâncias apropriadas (quando, por exemplo, a regressão volta suficientemente atrás), pode ser trazido de novo à luz (FREUD, 1930).

Dentre os vários artigos que tentaram dar conta dos meandros da mente humana, um dos textos mais famosos de Freud é Mal-estar da civilização, publicado em 1929, no qual questiona as raízes da infelicidade humana, o conflito entre instintos e cultura, e a forma que esse descompasso assumiu na civilização moderna. Freud, em determinado momento, chega a afirmar que "o que chamamos de nossa civilização é em grande parte responsável por nossa desgraça e que seríamos muito mais felizes se a abandonássemos e retornássemos às condições primitivas" (FREUD, 1929). Esse aparente retrocesso é justificado por ele, porque "constitui fato incontroverso que todas as coisas que buscamos a fim de nos protegermos contra as ameaças oriundas das fontes de sofrimento, fazem parte dessa mesma civilização" (FREUD, 1929).

Sendo ateu (embora tenha nascido em uma família judaica) e tentando mostrar a animalização humana (instintos), Freud argumenta que nem a religião foi capaz de humanizar o ser humano. Relembra o segundo mandamento do decálogo para ilustrar que foi uma tentativa, há mais de dois milênios, para que os homens se entendessem e para que limitassem sua índole mais agressiva. Afirma, entretanto que "nada mais vai tão fortemente contra a natureza original do homem" como a assertiva Amai-vos uns aos outros (FREUD, 1929). Justifica a luta e a competição como partes integrantes do homem desde as mais remotas épocas por terem impulsionado o progresso material que é vivenciado, todavia 
enfatiza que essas atitudes não deveriam ser necessariamente a causa de inimizade entre as pessoas. Acrescenta ainda que "quando, com crítica impiedosa, tentamos pôr à mostra as raízes de sua imperfeição [homem], estamos indubitavelmente exercendo um direito justo, e não nos mostrando inimigos da civilização" (FREUD, 1929), como se retratando de suas palavras anteriores que atacavam a civilização como uma forma de atraso moral da humanidade.

A Liga das Nações, antecessora da Organização das Nações Unidas (ONU), solicitou a Albert Einstein que escrevesse a Sigmund Freud para que ambos refletissem sobre a natureza da guerra e para que encontrassem uma forma de evitá-la ou de diminuir o seu alcance. Dessa troca de correspondências, datada de 1932, surgiu a publicação Por que a guerra?. O objetivo dessas cartas era que pessoas tão ilustres debatessem sobre o tema que estava mal resolvido e mal retratado pelas nações envolvidas. Cenas, como as que relata Paul Bäumer, ilustram algumas das consequências da guerra, não só aos soldados, mas também à população civil, a fuga de seus lares: "No caminho, encontramos habitantes que, expulsos de suas casas, fogem, arrastando seus bens em carroças, em carrinhos de bebês, ou às costas. Os vultos estão curvados, seus rostos cheios de sofrimento, de desespero, de pressa e de resignação" (REMARQUE, 1981, p. 191).

Einstein escreve a Freud, de Potsdam (Alemanha), em 30 de julho de 1932, perguntando ao professor (como se tratam no vocativo das missivas) se existiria alguma forma de livrar a humanidade da ameaça da guerra, pois todas as tentativas de solucioná-la configuraram-se em fracasso. Freud responde a Einsten, de Viena (Áustria), em setembro do mesmo ano, que "[...] o homem encerra dentro de si um desejo de ódio e de destruição" (1932). Mais ainda, que os animais resolvem seus conflitos por meio da violência, e o homem, sendo igualmente um animal, não se portaria de forma diferente. Freud alerta que, pelo aperfeiçoamento dos instrumentos de destruição, uma guerra futura poderia aniquilar um dos antagonistas ou, quem sabe, ambos.

Não tendo respostas concretas a dar para Einstein acerca de quando seria alcançada a paz pela humanidade, Freud salienta, no entanto, que a civilização deveria trazer consigo mudanças psíquicas, como a sublimação dos instintos, convertendo-os a ideais mais nobres, mas não soube dizer quando isso se concretizaria. Deixa claro, no entanto, que "[...] tudo o que estimula o crescimento da civilização trabalha simultaneamente contra a guerra" (1932).

Contemporâneo de Freud, Walter Benjamin trata de tema semelhante ao da neurose traumática em seu artigo Experiência e pobreza, publicado em 1933, cujo mote é o silenciamento pela falta do que dizer. Soldados que voltaram, embora vivos, sofreram experiências tão vazias, que optaram por calar-se, assim como Paul Bäumer quando visita sua família por uma licença curta: “[...] esforço-me terrivelmente para rir e falar, mas não consigo articular uma palavra, e assim fico na escada, infeliz, inútil e paralisado, e, contra minha vontade, as lágrimas deslizam-me pelo rosto" (REMARQUE, 1981, p. 130). Walter Benjamin, assim como Freud, embora pertencentes a ciências diferenciadas, analisaram o drama da contenção das emoções, dos sentimentos, à luz da vacuidade do que se fazia no início do século XX e as consequências danosas a quem dessas ações participava.

Walter Benjamin afirma que "[...] uma nova forma de miséria surgiu com esse monstruoso desenvolvimento da técnica, sobrepondo-se ao homem” (2010, p. 115). Além 
de todas as perdas materiais e humanas, pode-se acrescentar a pobreza do que ficou pendente: todas as ideias que não puderam ser desenvolvidas, o atraso da ciência - que se voltou ao armamento, em detrimento da saúde, do bem-estar. "Ficamos pobres", diz o filósofo. Essa sua asserção tão forte, certamente, deveu-se às teses que foram interrompidas, aos estudos que não puderam nem sequer ser iniciados, à desagregação da memória cultural e intelectual dos países envolvidos nesse combate, ao desaparecimento das construções seculares, dos monumentos, da cultura e da arte, danificados por bombas e, igualmente, à fuga e ao silenciamento dos homens talentosos que a Guerra expulsou da Alemanha e dos países dominados por ela.

"Surge assim uma nova barbárie [...]" (BENJAMIN, 2010, p. 115), afirma em Experiência e pobreza, pois o interesse de cada homem voltou-se para a sobrevivência de si próprio e de seus afetos, da obtenção de alimento, de abrigo, e não mais às soluções para um mundo melhor, ao progresso. Eis o silêncio, eis a falta das tentativas de acerto e de erro, consequentemente, da experiência positiva que mereça ser narrada, eis a falta do que contar aos descendentes, eis a pobreza. Na última página de Nada de novo no front, antes de morrer, Paul Bäumer conjectura consigo mesmo: "Que venham os meses e os anos, não conseguirão tirar mais nada de mim, não podem tirar-me mais nada. Estou tão só e sem esperança que posso enfrentá-los sem medo" (REMARQUE, 1981, p. 231).

\section{O desencanto: a crônica anunciada}

Criamos a época da velocidade, mas nos sentimos enclausurados dentro dela. A máquina, que produz abundância, tem-nos deixado em penúria. Nossos conhecimentos fizeram-nos céticos; nossa inteligência, empedernidos e cruéis.

Charles Chaplin, O grande ditador, 1940.

Os pensadores que se uniram em torno da Escola de Frankfurt não tinham uma linha de pensamento uniforme, debatiam temas não só relacionados à cultura e à arte, mas também aos problemas do início do século XX. Alguns, como Benjamin e Adorno, chegaram a aproximar-se do ideário marxista em determinado momento de suas carreiras, postura que não foi adotada por muito tempo. Embora sem se configurar como uma escola de fato, os participantes comungavam o desencanto em relação aos rumos a que se dirigia a sociedade mundial.

Em maio de 1944, Theodor W. Adorno e Max Horkheimer, exilados, quando de sua estada em Os Estados Unidos, escreveram Dialética do esclarecimento. Dentre as discussões em torno da cultura de massa, criticaram a inconsistência da ciência, a instrumentalização da linguagem, acusando a sociedade cujo "progresso irrefreável é a irrefreável regressão". Nesses escritos, Adorno afirma que: "o esclarecimento tem perseguido sempre o objetivo de livrar os homens do medo e de investi-los na posição de senhores. Mas a Terra totalmente esclarecida resplandece sob o signo de uma calamidade triunfal". Em outras palavras, há um desconforto desses filósofos quanto ao que, de fato, as luzes do esclarecimento trouxeram aos homens. Não há, evidentemente, uma negação do progresso e da sabedoria, mas um alerta de como e para que estão sendo usados; sob a falsa alegação do saber para todos, mais uma vez, "alguns são mais iguais que outros" (ORWELL, 2000, p. 135). 
No início de Nada de novo no front, o protagonista questiona a função de seus mestres: "Os professores deveriam ter sido para nós os intermediários, os guias para o mundo da maturidade, para o mundo do trabalho, do dever, da cultura e do progresso [...]" (REMARQUE, 1981, p. 16). Percebe-se, nessa passagem, uma crítica acerca do papel do esclarecimento, àqueles que deveriam iluminar e não levar seus alunos à morte. As ideias de Adorno contribuem a esta análise, pois criticam o patriotismo forçado, induzido pelos que idealizaram as guerras, afirmando que a "coletividade manipulada consiste na negação de cada indivíduo".

Segundo o filósofo, o conhecimento que libertaria todos e cada um, tão propalado pelo ideal iluminista, teve um retrocesso, e isso se percebe quando da crítica de Paul Bäumer a seus professores. O protagonista fala de Kantorek, um de seus mestres: "Kantorek nos leu tantos discursos nas nossas aulas de ginástica que a nossa turma inteira se dirigiu, sob o seu comando, ao destacamento do bairro e alistou-se (p. 15) [...] Houve milhares de Kantorek, todos convencidos de que agiam da melhor forma [...]" (REMARQUE, 1981, p. 16). Os postulados de Adorno ilustram a fala de Paul Bäumer, pois:

A horda, cujo nome sem dúvida está presente na organização da Juventude Hitleriana, não é nenhuma recaída na antiga barbárie, mas o triunfo da igualdade repressiva, a realização pelos iguais da igualdade do direito à injustiça. $\mathrm{O}$ mito de fancaria dos fascistas evidencia-se como o autêntico mito da Antiguidade, na medida em que o mito autêntico conseguiu enxergar a retribuição, enquanto o falso cobrava-a cegamente de suas vítimas.

Utopia é o título de uma obra escrita pelo inglês Thomas Morus, no período renascentista (1516), que trata de uma ilha imaginária onde existe uma sociedade perfeita e harmonizada. Segundo Cattani (2009, p. 328), a denotação da palavra proposta por Morus "vigorou durante dois séculos, afirmando a possibilidade de aperfeiçoamento do ser humano e de suas realizações [...]. A partir do século XVII, no entanto, o vocábulo incorporou um sentido depreciativo que permaneceu até o século XXI". A palavra utopia significa, portanto, um não lugar; ao mesmo tempo, algo que não tem condições de se realizar.

A partir do final da I Guerra, por suas consequências e pela iminência de outro grande conflito tão ou mais agressivo, a literatura ganhou outro contorno e começaram a proliferar visões distópicas ${ }^{7}$ do futuro da humanidade. Com uma visão extremamente pessimista acerca do avanço tecnológico, ilustram esse momento as obras de Adous Huxley (Admirável Mundo Novo), de George Orwell (1984) e de Ray Bradbury (Fahrenheit 451). São romances que vaticinam grandes problemas provindos de uma tecnologia muito avançada nas mãos de pessoas erradas, trazendo não o progresso, mas a manipulação das massas.

\footnotetext{
7 A literatura distópica leva o leitor do sonho ao pesadelo. Costuma apresentar pelo menos alguns dos seguintes traços: (a) tem conteúdo moral, projetando o modo como os nossos dilemas morais presentes figurariam no futuro; (b) oferece crítica social e apresenta as simpatias políticas do autor; (c) explora a estupidez coletiva; (d) o poder é mantido por uma elite, mediante a somatização e consequente alívio de certas carências e privações do indivíduo e (e) discurso pessimista, raramente "flertando" com a esperança.
} 
Por esse viés pessimista, aparentemente, toda a tecnologia serviu para brutalizar e não docilizar o Homem, ecoando nos estudos dos pensadores que foram, de modo ou outro, atingidos pelo conflito. Grandes flagelos da História, como Átila, Gengis Khan, Napoleão, apesar de suas incursões dominadoras e dos morticínios que causaram, foram superados em alcance e em devastação, se comparados às novas técnicas de matar muitos em pouco tempo: "Tornamo-nos animais selvagens. Não combatemos, defendemo-nos da destruição". (REMARQUE, 1981, p. 86).

\section{Considerações finais}

$\mathrm{O}$ avião e o rádio aproximaram-nos. A própria natureza dessas invenções clama pela bondade do homem, um apelo à fraternidade universal, à união de todos nós.

Charles Chaplin, O grande ditador, 1940.

As guerras são geradas por desentendimentos entre países ou entre localidades que não entram em consenso acerca de algum fator que os prejudicam, normalmente visando ao favorecimento de somente uma das partes. Outrossim, podem ser a resposta de um povo ao desmando de algum imperialista megalomaníaco. As consequências são sempre desastrosas à sociedade envolvida, pelas dívidas oriundas das batalhas, pelas mortes dos civis recrutados, pela destruição do patrimônio público. Não bastassem todas as perdas elencadas, somam-se as sequelas físicas e emocionais dos que a elas sobreviveram. Os locais que se envolveram em conflitos bélicos jamais serão os mesmos. A literatura, por sua vez, parte desses episódios e eterniza situações que não podem ser esquecidas pela lição que passam às gerações futuras.

Embora a grande repercussão do livro autobiográfico de Remarque, Regina Zilberman (2011) afirma que não se pode pensar que a experiência pessoal é necessária para se escrever sobre conflitos bélicos, pois alguns autores que se valeram desse tema como Erico Veríssimo, em Saga, e Marcel Proust, em Em busca do tempo perdido retrataram com muita propriedade o assunto, sem terem sido protagonistas de combates armados, bastando apenas sensibilidade e visão de mundo acurada para perceber o que por detrás se esconde acerca da visão oficial dos vencedores. O tema da guerra que, até o final do século XIX, tinha profundas ligações com as epopeias, tomou contornos próprios, desmistificando a ideia de que, mesmo sendo parte de um grupo vencedor, os protagonistas sempre triunfarão.

Remarque pode ser considerado um divisor de águas, pois, a partir de Nada de novo no front, há quem credite a ele o mérito de ser o fundador da tradição pacifista na ficção contemporânea ocidental e, simultaneamente, o arauto de ideias que questionavam a racionalidade humana. "Estamos aqui para defender a nossa pátria. Mas os franceses também estão aqui para defender a deles. Quem tem razão?" (REMARQUE, 1981, p. 164).

Passado quase um século do primeiro conflito bélico envolvendo várias nações, percebe-se que a civilização avança, o progresso material é evidente, mas a índole humana permanece inalterada. As religiões, como salientou Freud, não bastaram para que as pessoas se comportassem melhor e se aceitassem; novos cultos ainda se formam, prometendo a salvação aos que fizerem o bem, mas muito pouco resultado se obtém por esse caminho. Na contramão da promessa celestial, desde sempre e hodiernamente, muitas religiões servem de mote para outros novos conflitos. Muitos já se insurgiram contra a 
desarmonia entre os povos, e outras novas vozes se levantam todos os dias a favor da paz, mas, lamentavelmente, as ideias de Freud permanecem atuais: "A questão fatídica para a espécie humana parece-me ser saber se, e até que ponto, seu desenvolvimento cultural conseguirá dominar a perturbação de sua vida comunal causada pelo instinto humano de agressão e autodestruição".

\section{REFERENNCIAS}

ADORNO, W. Theodor; HORKHEIMER, Max. O conceito de esclarecimento. In: A dialética do esclarecimento: fragmentos filosóficos. Disponível em:

<http://antivalor2.vilabol.uol.com.br/textos/frankfurt/debate_de_index.html>. Acesso em: 20 fev. 2012.

ARRUDA, José Jobson de A.; PILETTI, Nélson. Toda a História: história geral e história do Brasil. 6. ed. São Paulo: Ática, 1996.

BARIFOUSE, Rafael. A fuga de cérebros da Alemanha nazista. Publicado em 06 fev. 2004. Atualizado em 14 out. 2009. Disponível em: <http://cienciahoje.uol.com.br/noticias/historia-da-ciencia-e-epistemologia/a-fuga-decerebros-da-alemanha-nazista>. Acesso em: 28 jan. 2012.

BENJAMIN, Walter. Experiência e pobreza. In: Obras escolhidas: magia e técnica, arte e política. v. 1. São Paulo: Brasiliense, 2010, p. 114-119.

CATTANI, Antônio D. Utopia. In: CATTANI, Antônio D. (Org.). Dicionário internacional da outra economia. Lisboa: Almedina, 2009. (p. 328-333).

CRAWFORD, Paulo. Albert Einstein: uma biografia muito breve. Disponível em:

<http://cosmo.fis.fc.ul.pt/ crawford/artigos/Albert\%20Einstein1b.pdf>. Acesso em: 28 jan. 2012.

FREUD, Sigmund. Além do princípio do prazer. In: Obras psicológicas de Sigmund Freud: escritos sobre a psicologia do inconsciente. v. II. Rio de Janeiro: Imago, 2006, p. 123-198. 28 jan. 2012.

O mal-estar da civilização. Disponível em: < http://livrosbpi.com/>. Acesso em:

; EINSTEIN, Albert. Um diálogo entre Freud e Einstein: por que a guerra? Disponível em: <http://library.fes.de/pdf-files/bueros/brasilien/05620.pdf>. Acesso em: 07 fev. 2012.

KAUFMANN, Dirk (ns). Bertold Bretch. Disponível em:

<http://www.dw-world.de/dw/article/0,450959,00.html>. Acesso em: 26 jan. 2012.

MAX Horkheimer. Biografia. Disponível em: <http://educacao.uol.com.br/biografias/maxhorkheimer.jhtm>. Acesso em: 21 fev. 2012.

MONTOYA, Randy. Armas químicas. Disponível em: <http://www.educacional.com.br/reportagens/armas/quimicas.asp>. Acesso em: 28 jan. 2012. 
ORWELL, George. A revolução dos bichos. Fonte Digital, 2000. Disponível em: <http://www.ebooksbrasil.org/adobeebook/animaisf.pdf>. Acesso em: 02 mar. 2012.

REMARQUE, Erich M. Nada de novo no front. São Paulo: Victor Civita, 1981.

SANTOS, C. A. Exílio nos EUA. Instituto de Física, UFRGS. Disponível em: <http://www.if.ufrgs.br/einstein/exilio.html>. Acesso em: 28 jan. 2012.

SCHILLING, Voltaire. Adorno e a cultura de massa. Disponível em: <http://educaterra.terra.com.br/voltaire/cultura/2003/09/08/000.htm>. Acesso em: 15 jan. 2012.

UTOPIA. In: PRIBERAN, Dicionário Priberam da Língua Portuguesa. Disponível em:

<http://www.priberam.pt/dlpo/default.aspx?pal=utopia>. Acesso em: 20 fev. 2012.

ZILBERMAN, Regina. Vivemos em tempos de guerra. Zero Hora. Caderno Cultura. 22 out. 2011.

Recebido em: 19/03/2015

Aceito em: 09/05/2015

${ }^{\text {i }}$ Doutora em Letras pela Universidade Federal do Rio Grande do Sul e mestre em Letras pela Pontifícia Universidade Católica do Rio Grande do Sul. Vinculada a Faculdade de Educação da Universidade Federal do Rio Grande do Sul. Email: marrodrigon@gmail.com. 